\title{
Factors influencing high callusing proliferation in cotton (Gossypium hirsutum L.)
}

\author{
R. Pushpa* and T. S. Raveendran \\ Centre for Plant Breeding and Genetics, Tamil Nadu Agricultural University, Coimbatore-641 003, India.
}

Accepted 8 May, 2013

\begin{abstract}
In vitro regeneration of cotton (Gossypium spp.) has been a subject of intense research for the last two decades because of the commercial value of the crop. A study was conducted to assess the callusing potential of two local cotton genotype varieties viz., MCU-5 and SVPR-2 and two exotic genotypes, Coker 310 and 312. High significant difference was observed between media composition, genotype and explant types used for callus induction. Among the 24 media composition screened for callusing, the medium CIM3 (MS + $0.1 \mathrm{mg} / \mathrm{l} 2,4-\mathrm{D}+0.5 \mathrm{mg} / \mathrm{l}$ kinetin) exhibited successful and faster induction of calli. Callus initiation was found to be quicker from hypocotyls than cotyledons. Calli developed from hypocotyl explants were large, rough and friable, while cotyledon-derived calli were friable and medium sized. Significantly higher callus induction frequencies were observed in hypocotyl (97.3\%) than cotyledon (95.8\%) explants which were collected from 7 day-old seedlings irrespective of genotype. Explants collected from younger (4 day-old) and older (14 day-old) plants showed poor and low callus induction frequencies.
\end{abstract}

Key words: Callus, cotyledon, Gossypium hirsutum, hypocotyl, media composition.

\section{INTRODUCTION}

Cotton (Gossypium hirsutum) which belongs to the family Malvaceae is an important fibre crop of global importance. It is also a source of oil and high quality protein meal and plays a significant role in the Indian economy. Globally, the cotton industry contributes millions of dollars annually in exports and imports. Among the cotton producing countries, India has the distinction of having the largest cotton growing area in the world with all four cultivated species under cultivation (Basu et al., 1995).

Genetic improvement of cotton through conventional breeding is limited by several factors including incompatibility barriers and time period for improved variety development (Munro, 1987). Although plant biotechnology seems to be an attractive way to improve cotton plant, its use requires an effective in vitro culture system using somatic tissues of plant. In vitro culture allows circumventing these difficulties: for example, callus obtained from which explant will be an ideal material for genetic transformations (Finer and McMullen, 1990). Cotton somatic embryogenesis was first observed by Price and Smith (1979), in Gossypium klotzschianum, but complete plantlets could not be regenerated from somatic embryos. Plant regeneration in cotton through somatic embryogenesis was first reported by Davidonis and Hamilton (1983) in two years old calli derived from cotyledons. Since then, numerous reports on somatic embryogenesis and regeneration (Leelavathi et al., 2004; Chaudhary et al., 2003; Shoemaker et al., 1986; Trolinder and Goodin, 1987, 1988a, b; Cousins et al., 1991; Kumeria et al., 2003; Rajasekaran et al., 1996) have been published. With regard to Indian cotton varieties 
success was reported so far only in two varieties viz., MCU 5 (Kumar and Pental, 1998) and SVPR 2 (Ganesan and Jayabalan, 2004). Factors involved in the initiation and maintenance of Gossypium species callus have been investigated by number of laboratories (Rao et al., 2006; Sun et al., 2006; Xie et al., 2007). The main factors determining the tissue culture response in cotton and other recalcitrant crops include genotype (Seabrook and Douglas, 2001), donor plant (Lu et al., 1984), type of growth regulators (Trolinder and Goodin, 1988; Sun et al., 2006) and sugar type (Ishii et al., 2004). An in-depth study of such factors would enable the development of genotype-specific culture methods to enhance the tissue culture response of the recalcitrant crops. The purpose of this study was to screen different cotton genotypes, media composition, explant age and type of explant (cotyledon, hypocotyls) for cotton callus induction.

\section{MATERIALS AND METHODS}

\section{Genotype}

In the present investigation, acid-delinted cotton seeds of elite cotton varieties, MCU 5, SVPR 2 and two Coker genotypes viz., Coker 310 and Coker 312 in which genetic transformation work was reported earlier (Kumar et al., 1998; Sakhanokho et al., 2001) were obtained from the germplasm collections of the Department of Cotton, Centre for Plant Breeding and Genetics, Tamil Nadu Agricultural University, Coimbatore.

\section{Surface sterilization}

Delinted seeds were surface sterilized with $70 \%$ ethanol for 2 min and then washed three times with sterile distilled water. They were again surface-sterilized with $0.1 \%$ mercuric chloride for $10 \mathrm{~min}$ followed by three washes with sterile distilled water.

\section{Seed germination}

The surface sterilized seeds were germinated on half strength MS (Murashige and Skoog, 1962) medium supplemented with one percent $(\mathrm{w} / \mathrm{v})$ sucrose and $10 \mathrm{~g} / \mathrm{l}$ agar. The $\mathrm{pH}$ of the medium was adjusted to 5.7 to 5.8 (by using $0.1 \mathrm{~N} \mathrm{KOH}$ or $0.1 \mathrm{~N} \mathrm{HCl}$ ) prior to autoclaving.

\section{Explant type}

Hypocotyl and cotyledonary explants obtained from seedlings (5 to 7 day-old) were used for callus induction. Both hypocotyl (4 to 6 $\mathrm{mm})$ and cotyledonary leaf $\left(16 \mathrm{~mm}^{2}\right)$ sections were plated onto callus induction medium (Figure 1). The explants of each genotype were plated on the following MS salts based compositions in three replications (Table 1) and subcultured on the same medium once in two weeks. The observations were recorded in each replication for all the genotypes and percentage of callusing was worked out.

\section{Effect of plant growth regulators on callus induction}

Both hypocotyl and cotyledon explants were cultured on MS basal medium supplemented with different concentrations and combinations of plant growth regulators to identify a medium that would produce, proliferate and maintain the callus cultures. The different media compositions and explants were tested for their effect on callus induction frequency as listed in Table 1. After autoclaving the media, the filter sterilized plant growth regulators were added onto the media at $42^{\circ} \mathrm{C}$. The $\mathrm{pH}$ of the media was adjusted to 5.8 prior to autoclaving the media for 15 minutes at $121^{\circ} \mathrm{C}$ and 15 psi pressure.

Callus initiation was evaluated one month after culture on the callus induction medium. The frequency of callus induction was expressed as percentage of the number of explants cultured and was calculated as given below:

$$
\text { Frequency of callus induction }(\%)=\frac{\text { Number of explants produced calli }}{\text { Total number of explants cultured }} \times 100
$$

\section{Effect of explant age}

To test the effect of age of the explants on callusing response, hypocotyls and cotyledon explants were excised from 5, 7, 10 and 12 day old seedlings. The callus induction frequency of hypocotyls and cotyledons was assessed on CIM3 medium.

\section{Experimental design and statistical analysis}

All tissue culture media were carried out in a completely randomized block design with three replications. Statistical analyses of the experiments were performed using AGRESAGDATA software.

\section{RESULTS AND DISCUSSION}

The frequency of callus induction and plant regeneration influenced was by several factors, including composition of the culture medium, explant sources and genotypes (Shengwei and Jingsan, 2000). The analysis of variance (Table 2) revealed significant differences in callus induction and callus characteristics due to media compositions, genotypes and explant types. The interaction effects were also significant.

Callus induction was observed in all media compositions in both explants. Among the various media compositions tested, CIM3 (MS + $0.1 \mathrm{mg} / \mathrm{l} 2,4-\mathrm{D}+0.5$ $\mathrm{mg} / \mathrm{l}$ kinetin) recorded maximum callus induction frequency with hypocotyl and cotyledon explants irrespective of genotypes studied (Table 3). Among the four genotypes, highest callus induction frequency of 97.7\% was observed in Coker 310. Callus maturation was achieved on MS basal medium in duration of 2 

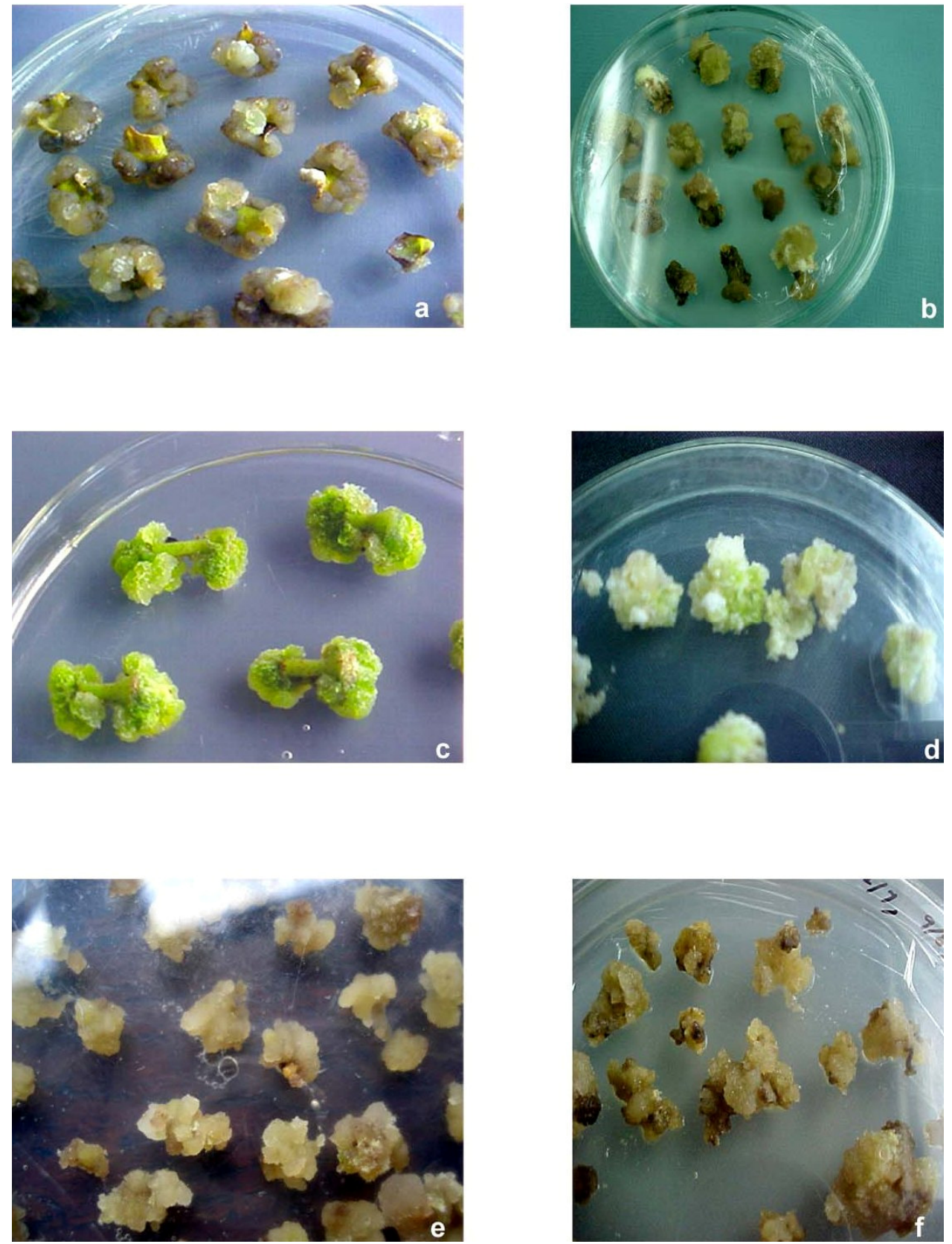

Figure 1. Effect of different plant growth regulators on callus induction. a: $2,4-D+$ kinetin (cotyledon), b: 2,4-D + kinetin (hypocotyl), c: NAA + kinetin, d: NAA + 2iP, e: 2,4-D + 2iP, f: picloram + kinetin.

months. Most of the published works had also reported MS based medium containing 2,4-D and kinetin as the best for callus induction (Trolinder and Goodin, 1987 and 1988a, b; Kumria et al., 2003; Choudhary et al., 2003; Haq and Zafar, 2004; Tohidfar et al., 2005; Zhao et al., 2006).

In the present study, it was observed that 2,4-D was more effective than NAA in producing embryogenic calli. Moreover, low levels of 2,4-D induced callus quickly and readily, whereas NAA required a longer time to produce significant amount of callus. This was in accordance with the results obtained by Trolinder and Goodin (1987, 1988a, b). Finer (1988) indicated that the callus induction was better at lower concentrations of auxins and cytokinins. Among the two explant types used in callus induction, hypocotyl explants $(97.7 \%)$ recorded higher callusing percentage than cotyledons (95.8\%). Such high callusing in hypocotyls was also reported by Trolinder and Goodin (1988a) and Sakhanokho et al. (1998, 2001 and 2004). Rapid callus development in hypocotyl tissue may shorten the culture duration, thus reducing the occurrence of somoclonal 
Table 1. Different media compositions used for callus induction from seedling explants.

\begin{tabular}{lccccc}
\hline \multirow{2}{*}{ Medium } & \multicolumn{5}{c}{ Media composition* } \\
\cline { 2 - 6 } & $\mathbf{2 , 4 - D}(\mathbf{m g} / \mathbf{l})$ & Kinetin (mg/l) & NAA (mg/l) & 2-ip (mg/l) & Picloram (mg/l) \\
\hline CIM1 & 0.1 & 0.1 & - & - & - \\
CIM2 & 0.1 & 0.3 & - & - & - \\
CIM3 & 0.1 & 0.5 & - & - & - \\
CIM4 & 0.5 & 0.1 & - & - & - \\
CIM5 & 0.5 & 0.5 & - & - & - \\
CIM6 & 0.5 & 1 & - & - & - \\
CIM7 & - & 0.1 & 2 & - & - \\
CIM8 & - & 0.5 & 2 & - & - \\
CIM9 & - & 1 & 2 & - & - \\
CIM10 & - & 0.1 & 1 & - & - \\
CIM11 & - & 0.5 & 1 & - & - \\
CIM12 & - & 1 & 1 & - & - \\
CIM13 & - & 0.5 & 0.1 & - & - \\
CIM14 & - & 0.5 & 0.5 & - & - \\
CIM15 & - & - & 1 & 0.5 & - \\
CIM16 & - & - & 0.5 & 0.1 & - \\
CIM17 & 0.1 & - & - & 0.1 & - \\
CIM18 & 0.1 & - & - & 0.5 & - \\
CIM19 & 0.1 & - & - & 1 & - \\
CIM20 & 0.5 & - & - & 0.1 & - \\
CIM21 & 0.5 & - & - & 0.5 & - \\
CIM22 & 0.5 & - & - & 1 & - \\
CIM23 & - & 0.3 & - & - & 0.5 \\
CIM24 & - & 0.3 & - & - & 1 \\
\hline
\end{tabular}

* All media were supplemented with MS salts and $30 \mathrm{~g} / \mathrm{l}$ maltose and solidified with $8 \mathrm{~g} / \mathrm{l}$ agar (CIM: callus induction medium).

Table 2. Analysis of variance for callus induction in cotton genotypes with different explants and media compositions.

\begin{tabular}{lcccc}
\hline Source & Degrees of freedom & Mean square & F- ratio & P-value \\
\hline Main effects & & & & \\
A : Medium & 23 & 708.5 & $185.7^{\star \star}$ & 0.00 \\
B : Genotype & 3 & 2044.2 & $536.0^{\star *}$ & 0.00 \\
C : Explant & 1 & 3835.5 & $1005.7^{\star \star}$ & 0.00 \\
Interaction effects & & & & \\
AB : Medium x Genotypes & 69 & 25.9 & $6.81^{* \star}$ & 0.00 \\
AC : Medium x Explants & 23 & 17.8 & $4.68^{\star \star}$ & 0.00 \\
BC : Genotypes x Explants & 3 & 12.2 & $3.20^{*}$ & 0.023 \\
ABC: Medium x genotypes x explants & 69 & 11.30 & $2.96^{\star \star}$ & 0.00 \\
Error & 384 & 3.81 & & \\
\hline
\end{tabular}

*Significant at $5 \%$ level, ** significant at $1 \%$ level.

variation, a major problem in cotton tissue culture (Sakhanokho et al., 2004). Among the cotton genotypes studied, Coker 310 exhibited the highest callus induction frequency than MCU 5, SVPR 2 and Coker 312. Callus induction frequency was more in hypocotyl explants than cotyledon explants isolated from 7 day-old seedlings. Significantly higher callus induction frequencies were observed for hypocotyl $(97.3 \%)$ than cotyledon (94.6\%) explants collected from 7 days-old seedlings irrespective of genotypes studied (Figures 2 
Table 3. Effects of plant growth regulators on callus induction from cotyledon and hypocotyls explants of cotton variety.

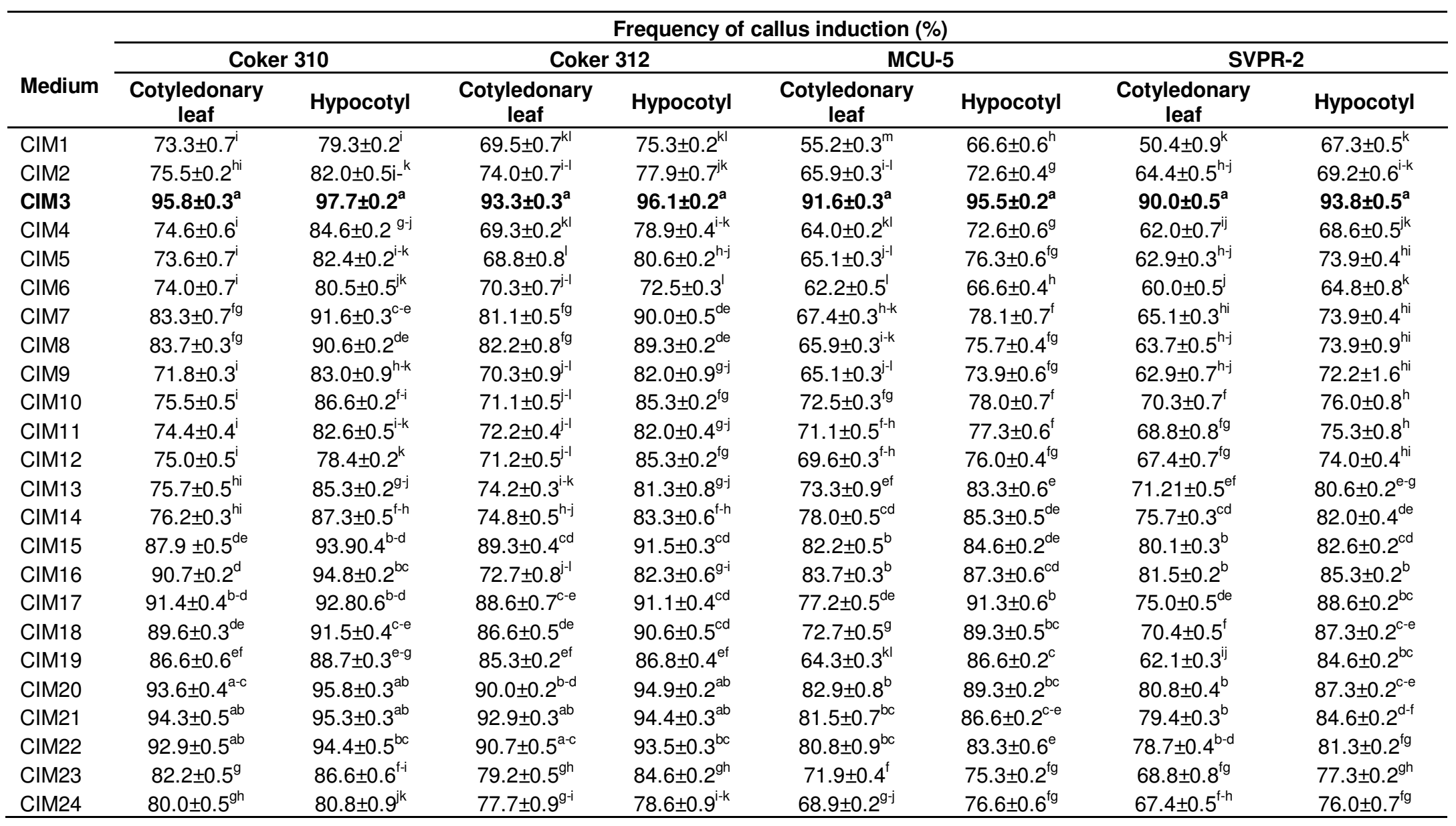

Values represent the mean \pm standard error of three replications. In a column, means followed by same letters are not significant at $5 \%$ level by LSD.

and 3). Explants collected from younger and older seedlings of 4 and 12 days old exhibited only low callus induction frequencies. It was also observed that 7 days-old seedlings provided explants (cotyledon and hypocotyls) which were superior in callusing response. Such variable responses in callus induction for different age have been reported in cotton (Sakhanokho et al., 1998; Nobre et al., 2001) and also in other species (Pereira et al., 2000; Dhar and Joshi, 2005). Such variations can be attributed to the physiological condition of the explant, which is determined by genetic factors (Nagarathna et al., 1991). Younger explants exhibit greater morphogenic potential than older explants in view of their higher metabolically active cells. From the study, it is clear that the effectiveness of various callus initiation media for each of the cotton genotypes 


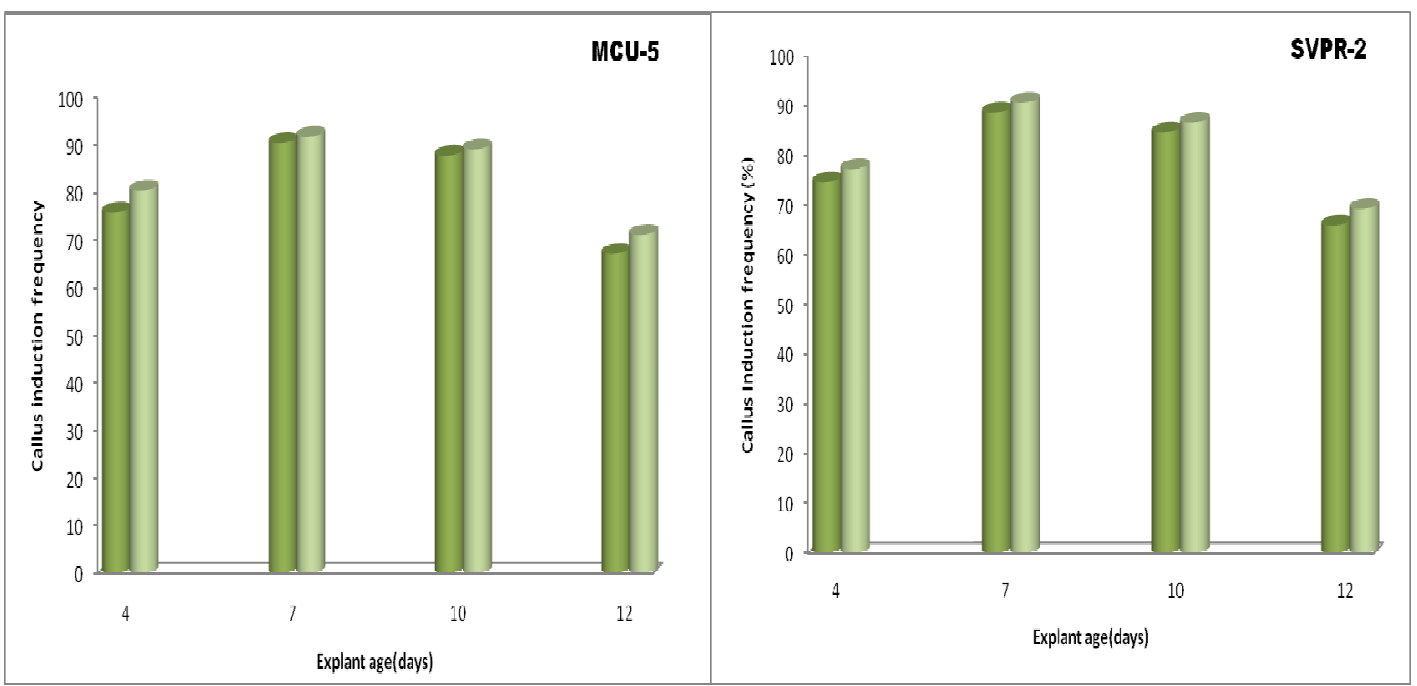

Figure 2. Effect of age of explants on callus induction frequency on Indian genotype.

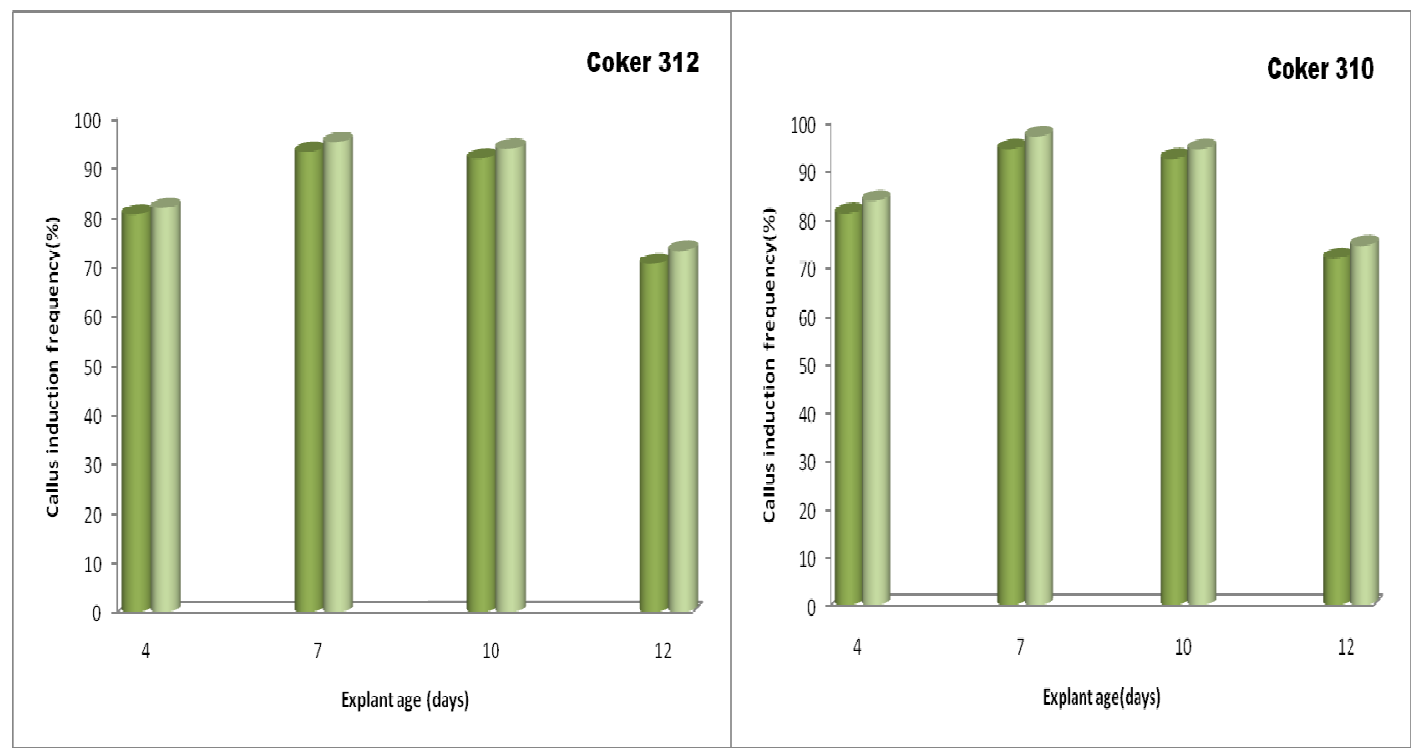

Figure 3. Effect of age of explants on callus induction frequency on Coker genotype. $\square$ hypocotyl.

Totyledon;

tested suggested that the optimal media combinations and genotypes are dependent on each other. Hormonal and nutritional conditions could also contribute to the differential callusing response. Callus selection is an important step in cotton tissue culture which plays a major role in the successful regeneration of cotton via somatic embryogenesis.

\section{REFERENCES}

Basu AK, Narayanan SS, Bhat MG (1995). Hybrid cottons: Historical development, present status and future perspective in Indian context.
In: Hybrid research and development (Eds.) S. Mauria, Indian Society. Seed Technol. New Delhi, pp. 63-80.

Chaudhary B, Kumar S, Prasad KVSK, Oinam GS, Burma PK, Pental D (2003). Slow desiccation leads to high-frequency shoot recovery from transformed somatic embryos of cotton (Gossypium hirsutum L. CV. Coker 310 FR). Plant Cell Rep. 21:955-960.

Cousins YL, Lyon BR, Llewellyn DJ (1991). Transformation of an Australian cotton cultivar. Prospects for cotton improvement through genetic engineering. Aust. J. Plant Physiol. 18:481-494.

Davidonis GH, Hamilton R (1983). Plant regeneration from callus tissue of Gossypium hirsutum L. Plant Sci. Lett. 32:89-93.

Dhar U, Joshi M (2005). Efficient plant regeneration protocol through callus for Saussurea obvallata (DC) Edgew. (Astraceae): Effect of explant type, age and plant growth regulators. Plant Cell Rep. 24:195-200.

Finer JJ, McMullen MD (1990). Transformation of cotton (Gossypium 
hirsutum L.) via particle bombardment. Plant Cell Rep. 8:586-589.

Ganesan M, Jayabalan N (2004). Evaluation of haemoglobin (erythrogen): For improved somatic embryogenesis and plant regeneration in cotton (Gossypium hirsutum L. CV. SVPR 2). Plant Cell Rep. 23:181-187.

Haq I, Zafar Y (2004). Effect of nitrates on embryo induction efficiency in cotton (Gossypium hirsutum L. Afr. J. Biotechnol. 3:319-323.

Ishii Y, Takamura T, Goi M, Tanaka M (2004). Callus induction and somatic embryogenesis of Phalaenopsis. Plant Cell Rep. 17(6):446450.

Kumar S, Pental D (1998). Regeneration of Indian cotton variety MCU-5 through somatic embryogenesis. Curr. Sci. 74:538-540.

Kumria R, Leelavathi S, Bhatnagar RK, Reddy VS (2003). Regeneration and genetic transformation of cotton: Present status and future perspectives. Plant Tiss. Cult. 13(2):211-225.

Leelavathi S, Sunnichan VG, Kumria R, Vijaykanth GP, Bhatnagar RK, Reddy VS (2004). A simple and rapid Agrobacterium-mediated transformation protocol for cotton (Gossypium hirsutum): Embryogenic calli as a source to generate large numbers of transgenic plants. Plant Cell Rep. 22:465-470.

Lu CY, Chandler SF, Vasil IK (1984). Somatic embryogenesis and plant regeneration from cultured embryos of rye (Secale cereale L.). J. Plant Physiol. 115:237-244.

Munro JM (1987) Cotton. Trop. Agric. Ser. 2:170-172.

Murashige T, Skoog F (1962). A revised medium for rapid growth and bioassays with tobacco tissue culture. Physiol. Plant. 15:474-497.

Nagarathna KC, Prakash HS, Shetty HS (1991). Genotypic effects on the callus formation from different explants of pearl millet $B$ lines. Adv. Plant Sci. 4:82-86.

Nobre J, Keith DJ, Dunwell JM (2001). Morphogenesis and regeneration from stomatal guard cell complexes of cotton (Gossypium hirsutum L.). Plant Cell Rep. 20:8-15.

Pereira AMS , Bertoni BW, Gloria B A, Araiyo A R B, Janauario AH, Loureno MV, Franca (2000). Micropropagation of Pathomorphe umbellate via direct organogenesis from leaf explants. Plant Cell Tiss. Org. Cult. 60:47-53.

Price HJ, Smith RH (1979). Somatic embryogenesis in suspension cultures of Gossypium klotzschianum Anderss. Planta. 145:305-307.

Rao A, Hussain S, Shahzad M, Bokhari SY, Raza M, Rakha A, Majeed A, Shahid A, Saleem Z, Husnain T, Riazuddin S (2006). Somatic embryogenesis in wild relatives of cotton (Gossypium spp.). J. Zhejiang Univ. Sci. 7(4):291-298.

Sakhanokho HF, Sharma GD, Zipf A, Sana S, Rajasekaran K (1998). Tissue culture potential of diverse diploid and tetraploid cotton genotypes. In: Proc. Beltwide Cotton Prod. Res. Conf. pp. 590-593.

Sakhanokho HF, Ozias-Akins P, May OL, Chee PW (2004). Induction of somatic embryogenesis and plant regeneration in select Georgia and Pee Dee cotton lines. Crop Sci. 44:91-95.

Sakhanokho HF, Zipf A, Rajasekaran K, Saha S, Sharma GC (2001). Induction of highly embryogenic calli and plant regeneration in Upland and Pima cottons. Crop Sci. 41:1235-1240.
Seabrook JA, Douglass LK (2001). Somatic embryogenesis on various potato tissues from a range of genotypes and ploidy levels. Plant Cell Rep. 20:175-182.

Shengwei Z, Jingsan S (2000). Rapid plant regeneration from cotton (Gossypium hirsutum L.). Chin. Sci. Bull. 45:1771-1773.

Shoemaker RC, Couche LJ, Galbraith DW (1986). Characterization of somatic embryogenesis and plant regeneration in cotton (Gossypium hirsutum L.). Plant Cell Rep. 3:178-181

Sun Y, Zhang X, Huang C, Guo X, Nie Y (2006). Somatic embryogenesis and plant regeneration from different wild diploid cotton (Gossypium ) species. Plant Cell Rep. 25(4):289-296.

Trolinder NL, Goodin JR (1987). Somatic embryogenesis and plant regeneration in cotton (Gossypium hirsutum L.). Plant Cell Rep. 6:231-234.

Trolinder NL, Goodin JR (1988a). Somatic embryogenesis in cotton (Gossypium). I. Effects of source of explant and hormone regime. Plant Cell Tiss. Org. Cult. 12:178-181.

Trolinder NL ,Goodin JR (1988b). Somatic embryogenesis in cotton (Gossypium). II. Requirements for embryo development and plant regeneration. Plant Cell Tiss. Org. Cult. 12:43-53.

Tohidfar M, Mohammadi M, Ghareyazie B (2005). Agrobacteriummediated transformation of cotton (Gossypium hirsutum) using a heterogeous bean chitinae gene. Plant Cell Tiss. Org. Cult. 83:83-96.

Xie D , Jin S, Guo X, Zhang X (2007). Somatic embryogenesis and plant regeneration in cotton cultivars from yellow and Yangtze River planting areas. Acta Agron. Sin. 33:394-400.

Zhao FY, Li YF, Xu P (2006). Agrobacterium - Mediated transformation of cotton (Gossypium hirsutum L. CV. Zhongmian 35) using glyphosate as a selectable marker. Biotech. Lett. 28:1199-1207. 